\title{
Regulation of cyclooxygenase activity by metamizol
}

\author{
Carmen Campos ${ }^{\mathrm{c}, 1}$, Rosa de Gregorio a , Raquel García-Nieto ${ }^{\mathrm{b}}$, Federico Gago ${ }^{\mathrm{b}}$, \\ Pablo Ortiz ${ }^{c}$, Susana Alemany ${ }^{\mathrm{a}, *}$ \\ ${ }^{a}$ Instituto de Investigaciones Biomédicas (CSIC), Departmento de Bioquímica de UAM, Arturo Duperier 4, E-28029 Madrid, Spain \\ ${ }^{\mathrm{b}}$ Departamento de Farmacología, Universidad de Alcalá, E-28871 Alcalá de Henares, Madrid, Spain \\ ${ }^{c}$ Medical Department, Boehringer Ingelheim, Spain
}

Received 18 March 1999; received in revised form 24 June 1999; accepted 29 June 1999

\begin{abstract}
The ability of metamizol to inhibit cyclooxygenase- 1 and cyclooxygenase- 2 activities has been evaluated using different cyclooxygenase sources. Metamizol inhibited purified cyclooxygenase- 1 and cyclooxygenase- 2 with an $\mathrm{IC}_{50}$ of about $150 \mu \mathrm{g} / \mathrm{ml}$. A similar IC ${ }_{50}$ value for cyclooxygenase-2 was obtained in lipopolysaccharide-activated broken murine macrophages. Consistent with these findings, molecular models of the complexes between cyclooxygenase-1 or cyclooxygenase- 2 with 4-methylaminoantipyrine, the major active derivative of metamizol, suggested a common binding mode to both isoforms. In intact cells, however, the inhibition profiles were markedly different. The $\mathrm{IC}_{50}$ values of metamizol for cyclooxygenase-1 in intact bovine aortic endothelial cells (BAEC) cells and human platelets were $1730 \pm 150 \mu \mathrm{g} / \mathrm{ml}$ and $486 \pm 56 \mu \mathrm{g} / \mathrm{ml}$, respectively. Inhibition of cyclooxygenase-2 activity in murine macrophages and primary human leukocytes activated by lipopolysaccharide yielded $\mathrm{IC}_{50}$ values of $12 \pm 1.8 \mu \mathrm{g} / \mathrm{ml} \mathrm{and} 21 \pm 2.9 \mu \mathrm{g} / \mathrm{ml}$, respectively. These data indicate that the $\mathrm{IC}_{50}$ values obtained with purified enzymes or disrupted cells cannot always be extrapolated to the cyclooxygenase inhibitory activity of nonsteroidal antiinflammatory drugs (NSAIDs) in intact cells. The data presented here also indicate that cyclooxygenase-2 inhibition could play an important role in the pharmacological effects of metamizol. (C) 1999 Elsevier Science B.V. All rights reserved.
\end{abstract}

Keywords: Cyclooxygenase; Nonsteroidal antiinflammatory drug (NSAID); Metamizol; Molecular modelling

\section{Introduction}

The rate limiting step in the synthesis of prostaglandins and thromboxanes is the conversion of arachidonate to prostaglandin $\mathrm{H}_{2}$, which is catalyzed by two isozymes cyclooxygenase-1 and cyclooxygenase-2 (for a review, see Smith et al., 1998 and Vane et al., 1998). The first isozyme, cyclooxygenase-1, is a constitutive enzyme expressed in many tissues and also in platelets (Funk et al., 1991; Simmons et al., 1991). Cyclooxygenase-1 has been involved in "housekeeping" functions, such as coordinating the actions of circulating hormones, mucose gastric protection and regulating vascular homeostasis (Smith et al., 1989). In contrast, cyclooxygenase- 2 is an inducible

\footnotetext{
* Corresponding author. Tel.: + 34-91-3975445; fax: + 34-91-5854587; E-mail: salemany@biomed.iib.uam.es

${ }^{1}$ R. de Gregorio and C. Campos have contributed equally to this work.
}

enzyme and is primarily associated with inflammation. Cyclooxygenase- 2 is induced in a variety of cell types by diverse stimuli including cytokines, growth factors, mitogens and tumour promoters (Kujubu et al., 1991; Lee et al., 1992; DeWitt and Meade, 1993; Ristimaki et al., 1994; Coffey et al., 1997). In brain and spinal cord cyclooxygenase-2 is constitutively expressed (McCormak, 1994; Cashman, 1996; Yaksh et al., 1998).

Cyclooxygenase- 1 and cyclooxygenase- 2 are encoded by different genes (Yokoyama and Tanabe, 1989; Kraemer et al., 1992) but they exhibit a $62 \%$ homology at the aminoacid level. The three-dimensional structures of both enzymes have been solved by X-ray crystallography (Picot et al., 1994; Kurumbail et al., 1996), and all the residues that make up the cyclooxygenase active site have been shown to be identical except for the amino acid at position 523 , which is an isoleucine in cyclooxygenase- 1 but a valine in cyclooxygenase- 2 . This residue is found at the bottom of a hydrophobic channel where nonsteroidal anti- 
inflammatory drugs (NSAIDs) bind. A mutant of cyclooxygenase-2 in which valine ${ }^{523}$ is exchanged for isoleucine shows inhibitor binding and selectivity profiles comparable to those of wild-type cyclooxygenase-1 (Gierse et al., 1996; Guo et al., 1996).

Metamizol is a prodrug which, at room temperature and in an atmosphere with oxygen, is spontaneously, nonenzymatically converted to 4-methylaminoantipyrine (Levy, 1986; Levy et al., 1995). Subsequently, the $N$-methyl side chain of 4-methylaminoantipyrine is oxidized to yield 4formylaminoantipyrine, which is further converted to 4aminoantipyrine. Therefore, it is accepted that metamizol in aqueous solution and in the presence of oxygen consists of a group of several pyrazolone derivatives (Brodgen, 1986; Levy, 1986; Levy et al., 1995), of which 4-methylaminoantipyrine is pharmacologically the most important (Brodgen, 1986; Levy, 1986; Levy et al., 1995; Vlahov et al., 1990). In the present paper hereafter, the term metamizol will encompass this whole set of pyrazolone derivatives (Fig. 1A), all of which have analgesic, antipyretic, and relatively weak antiinflammatory properties.

It has been proposed that the antinociceptive action of metamizol is at least partially centrally mediated (Carlsson et al., 1986; Gelgor et al., 1992; Tortorici and Vanegas, 1995), even though an association of metamizol with opioid receptors is unlikely (Beirith et al., 1998; Taylor et al., 1998). On the other hand, a dissociation between the antiinflammatory and analgesic effects of metamizol, and inhibition of prostaglandins synthesis was reported prior to the discovery of cyclooxygenase-2 (Dembinska-Kiec et al., 1976; Brune, 1983; Eldor et al., 1984; Lorenzetti and Ferreira, 1985).

The importance of the discovery of the inducible form of cyclooxygenase is highlighted by the differences in pharmacology between the two isozymes. The antiinflammatory capacity of the different NSAIDs is now proposed to be associated with the capacity of inhibiting cyclooxygenase-2 activity. A central analgesic effect of NSAIDs has also been proposed (McCormak, 1994; Cashman, 1996; Yaksh et al., 1998), which is probably mediated by regulation of cyclooxygenase-2 activity in the spinal cord (Dirig et al., 1997; Smith et al., 1998). Regulation of cyclooxygenase-1 activity, on the other hand, is thought to be responsible for the gastric and renal side effects of NSAIDs, as well as for their antithrombotic activity (for a review, see Pairet and Engelhardt, 1996; Vane and Botting, 1998). Cyclooxygenase- 2 is presently regarded as an important target for the development of novel NSAIDs with improved toxicological profiles.

In this paper we evaluate the capacity of metamizol to inhibit cyclooxygenase- 1 and cyclooxygenase- 2 activities using different cell systems, as well as purified cyclooxy-<smiles>Cc1c(N(C)CS(=O)(=O)O[Na])c(=O)n(-c2ccccc2)n1C</smiles>

metamizol<smiles>Cc1c(NC=O)c(=O)n(-c2ccccc2)n1C</smiles>

\section{4-formylaminoantipyrine}<smiles>CNc1c(C)n(C)n(-c2ccccc2)c1=O</smiles>

\section{4-methylaminoantipyrine}<smiles>Cc1c(N)c(=O)n(-c2ccccc2)n1C</smiles>

4-aminoantipyrine

Fig. 1. Binding mode of 4-methylaminoantipyrine in the active site of cyclooxygenase-2. (Above) Chemical formulae of metamizol and its active derivatives. (Right page) Molscript representation (Kraulis, 1991) of 4-methylaminoantipyrine (thicker bonds) docked in the active site of human cyclooxygenase-2, as proposed by programs GRID and AutoDock. In this orientation the interactions between the inhibitor and the enzyme are optimized. Relevant residues are shown as ball-and-stick and have been labeled (the numbering scheme follows the convention for the sheep cyclooxygenase-1 structure). This binding mode is identical to that found in the 4-methylaminoantipyrine-cyclooxygenase-1 complex and is presumed to be the same for the active derivatives shown in A. 


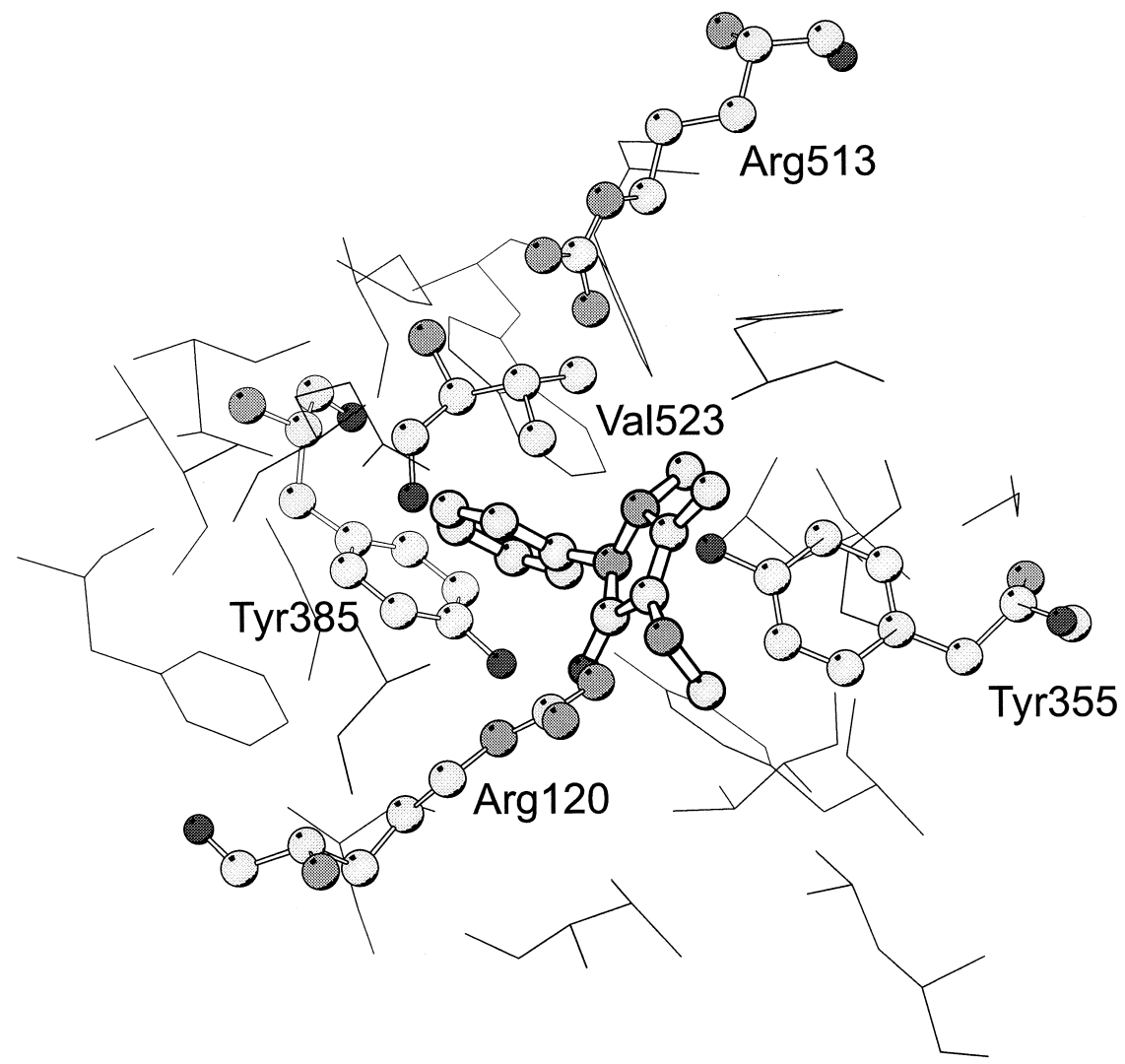

Fig. 1 (continued).

genase- 1 and cyclooxygenase- 2 . We also present a molecular model of the interaction between 4-methylaminoantipyrine, the pharmacologically most important derivative of metamizol, and the cyclooxygenase active sites of both cyclooxygenase- 1 and cyclooxygenase- 2 .

\section{Material and methods}

2.1. Docking of 4-methyl-amino-antipyrine into the cyclooxygenase active sites of human cyclooxygenase-1 and cyclooxygenase- 2

The experimentally determined three-dimensional structures of ovine cyclooxygenase-1 (Picot et al., 1994) and mouse cyclooxygenase-2 (Kurumbail et al., 1996), together with our homology-based models of their human counterparts (García-Nieto et al., 1999), were studied. Two possible conformers of 4-methylaminoantipyrine were initially considered differing in the orientation of the $N$-methyl substituent relative to the plane of the pyrazole ring, and their geometries were optimized by using the semiempirical molecular orbital AM1 method (Dewar et al., 1985). Atom-centered charges were then derived by fitting the calculated molecular electrostatic potential to a monopole-monopole expression (Besler et al., 1990). Then, the Monte Carlo simulated annealing technique implemented in AutoDock (Morris et al., 1996) was used to generate different conformations and orientations of 4-methylaminoantipyrine within the enzyme binding sites and to evaluate the energy of each configuration. In addition, the active sites of these enzymes were probed for regions of steric and electrostatic complementarity with the functional groups present in 4-methylaminoantipyrine (i.e., aliphatic and aromatic carbons, carbonyl oxygen, and amino and heterocyclic ring nitrogens) using program GRID (Goodford, 1985). The 4-methylaminoantipyrine favoured by AutoDock was then used as a rigid ligand for the GROUP module of GRID (version 16, Molecular Discovery, 1997), which automatically produces the ligand orientation that best matches the calculated maps for the atom probes.

\subsection{Measurement of purified cyclooxygenase activities}

Purified cyclooxygenase-1 and cyclooxygenase-2 were obtained from Cayman Chemicals (Ann Arbor, MI). Enzyme activity was measured by conversion of $\left[{ }^{14} \mathrm{C}\right]$ arachidonic acid to prostaglandins, after separation by thin layer chromatography (TLC) (Mitchell et al., 1994). The reaction was started by the addition of 10 units of the different enzymes to a reaction mixture made up to a final volume of $1 \mathrm{ml}$, containing $50 \mathrm{mM}$ Tris buffer $\mathrm{pH} 8$, glutathione (5 $\mathrm{mM})$, epinephrine $(5 \mathrm{mM})$, hematin $(1 \mu \mathrm{M}), 1 \times 10^{5} \mathrm{dpm}$ $\left[{ }^{14} \mathrm{C}\right]$ arachidonic acid (Amersham), 6.6 $\mu \mathrm{M}$ arachidonic 
acid and different concentrations of metamizol. Samples were incubated in a shaking water bath at $37^{\circ} \mathrm{C}$ for $10 \mathrm{~min}$, after which the reaction was stopped by adding $30 \mu l$ of 1 $\mathrm{mM} \mathrm{HCl}$. One milliliter of saturated $\mathrm{NaCl}$ solution was added to each sample followed by $1.5 \mathrm{ml}$ of ethylacetate. After mixing the samples by vortexing, they were centrifuged at $575 \times g$ for $10 \mathrm{~min}$ and the ethyl acetate layer was transferred to a clean tube and dried under nitrogen stream. Prostaglandins were separated by TLC. Each sample was redissolved in $30 \mu \mathrm{l}$ of chloroform/methanol, 2:1 $(\mathrm{v} / \mathrm{v})$, and $20 \mu \mathrm{l}$ were applied onto a glass-backed silica gel plate (Merck). The TLC plate was developed for approximately $90 \mathrm{~min}$ at room temperature in a solvent consisting of the upper phase of ethyl acetate/trimethyl pentane/acetic acid/water, 110:50:20:100 (v/v). For detection of the ${ }^{14} \mathrm{C}$-labelled prostaglandins an autoradiography in an Instant Imager was performed.

\subsection{Measurement of cyclooxygenase-1 activity in intact cells}

Bovine aortic endothelial cells (BAEC), maintained in Dulbecco's Modified Eagle Medium (DMEM) with 10\% fetal calf serum, $4 \mathrm{mM}$ glutamine, $50 \mu \mathrm{g} / \mathrm{ml}$ gentamicin at $37^{\circ} \mathrm{C}$, were incubated for $30 \mathrm{~min}$ with different concentrations of metamizol $(125-4000 \mu \mathrm{g} / \mathrm{ml})$ or with indomethacin $(0.1-100 \mu \mathrm{g} / \mathrm{ml})$, after which arachidonic acid was added to a final concentration of $30 \mu \mathrm{M}$. Cells were incubated for further $15 \mathrm{~min}$ at $37^{\circ} \mathrm{C}$. The medium was then removed, and a radioimmunoassay kit (Amersham) was used to measure the formation of 6-keto-prostaglandin $\mathrm{F}_{1 \alpha}$. Metamizol did not interfere with the measurement of 6-keto-prostaglandin $\mathrm{F}_{1 \alpha}$.

Fresh human platelets were isolated as described by Font et al. (1992). Acid-citrate-dextrose-anticoagulant blood samples were centrifuged at $180 \times g$ for $10 \mathrm{~min}$ at $20^{\circ} \mathrm{C}$ and the supernatant containing the platelets was diluted $1 / 1(\mathrm{v} / \mathrm{v})$ with phosphate saline buffer (PBS). Cells were incubated with different concentrations of metamizol $(125-4000 \mu \mathrm{g} / \mathrm{ml})$ and stimulated with calcium ionophore A23187 $(0.25 \mu \mathrm{M})$. The levels of thromboxane $\mathrm{B}_{2}$ in the incubation media after 5 min of stimulation were measured with a thromboxane $\mathrm{B}_{2}$ enzyme immunoassay system (Amersham). Metamizol did not interfere with the measurement of thromboxane $B_{2}$.

\subsection{Measurement of cyclooxygenase-2 activity in intact cells}

Murine monocyte-macrophage J774A.1 cells, in RPMI 1640 medium supplemented with $10 \%$ fetal calf serum, gentamicin $(50 \mu \mathrm{g} / \mathrm{ml})$ (complete medium) at $0.5 \times 10^{6}$ cells $/ \mathrm{ml}$, were treated with lipopolysaccharide at $1 \mu \mathrm{g} / \mathrm{ml}$ for $12 \mathrm{~h}$ to induce cyclooxygenase-2. Complete medium was then changed and different concentrations of metami- zol or indomethacin were added and the cells incubated for $30 \mathrm{~min}$ at $37^{\circ} \mathrm{C}$. The medium was then removed and prostaglandin $\mathrm{E}_{2}$ levels were analyzed by prostaglandin $\mathrm{E}_{2}$ enzyme immunoassay system (Amersham). Metamizol did not interfere with the measurement of prostaglandin $E_{2}$.

Human peripheral leukocytes from Buffy-Coat were separated using Histopaque 1099 (Sigma) as described by Tavares and Bennett (1993) and incubated for $2 \mathrm{~h}$ in complete medium at $0.5 \times 10^{6}$ cells $/ \mathrm{ml}$. Subsequently, the cells were incubated for $12 \mathrm{~h}$ with or without lipopolysaccharide $(3 \mu \mathrm{g} / \mathrm{ml})$, and in the presence or absence of different concentrations of metamizol. The prostaglandin $\mathrm{E}_{2}$ released to the incubation media was measured by radioimmunoassay as described above.

\subsection{Measurement of cyclooxygenase-2 activity in macrophage cell extracts}

Lipopolysaccharide at $1 \mu \mathrm{g} / \mathrm{ml}$ was added for $12 \mathrm{~h}$ to confluent murine macrophages after which cells were washed and homogenized with a glass teflon homogenizer in $50 \mathrm{mM}$ Tris buffer ( $\mathrm{pH} 7.4)$ containing $1 \mathrm{mM}$ phenylmethyl sulfonyl fluoride, $50 \mu \mathrm{M}$ pepstatin $\mathrm{A}$, and $0.2 \mathrm{mM}$ leupeptin. Broken cells were incubated at $37^{\circ} \mathrm{C}$ in the presence of different concentrations of metamizol or indomethacin for $30 \mathrm{~min}$. About $30 \mu \mathrm{M}$ of arachidonic acid was then added, and the reaction continued for a further 15 min. The reaction was stopped by boiling, and after centrifugation at $10,000 \times g$ for $30 \mathrm{~min}$, prostaglandin $\mathrm{E}_{2}$ was measured in the supernatant as described above.

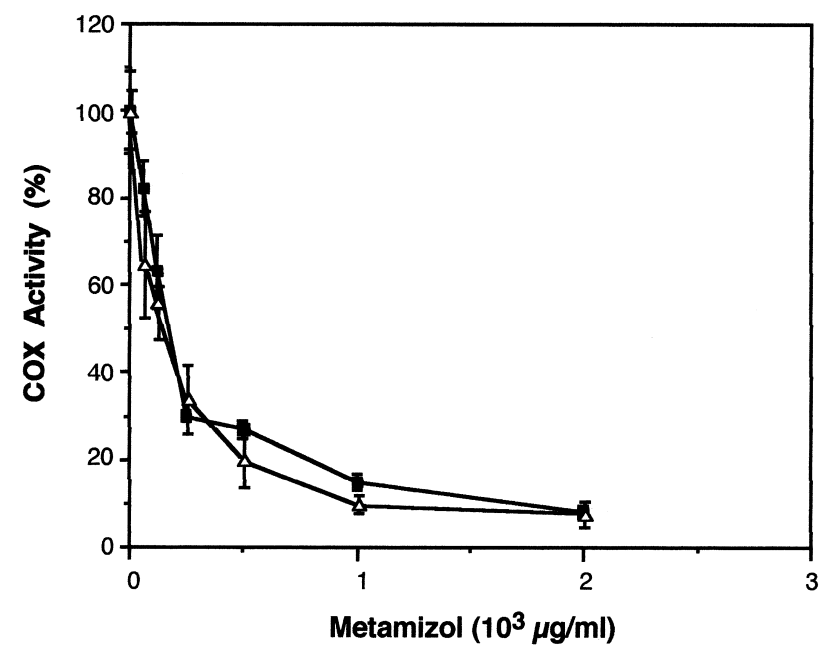

Fig. 2. Regulation of purified cyclooxygenase-1 and cyclooxygenase-2 activity by metamizol. Cyclooxygenase enzymes were incubated with saturating doses of arachidonic acid in the presence of different doses of metamizol. The data are expressed as mean \pm S.D. from three different experiments performed in duplicate. $\triangle$ : Cyclooxygenase- 1 activity. Cyclooxygenase-2 activity. 


\section{Results}

\subsection{Docking of 4-methylaminoantipyrine into the active} sites of human cyclooxygenase-1 and cyclooxygenase-2

Both GRID and AutoDock found the same binding orientation for 4-methylaminoantipyrine, the main active derivative of metamizol, irrespective of the isozyme considered. The molecule binds at the bottom of the substrate channel placing the phenyl ring above the plane of $\mathrm{Tyr}^{385}$, the 4-amino group in close proximity to the hydroxyl of $\mathrm{Tyr}^{355}$, and the $\mathrm{N}^{2}$ ring nitrogen facing the residue at position 523 (Fig. 1B). The smaller size of the side chain of valine relative to that of isoleucine at this position allows the main substrate channel in cyclooxygenase- 2 to
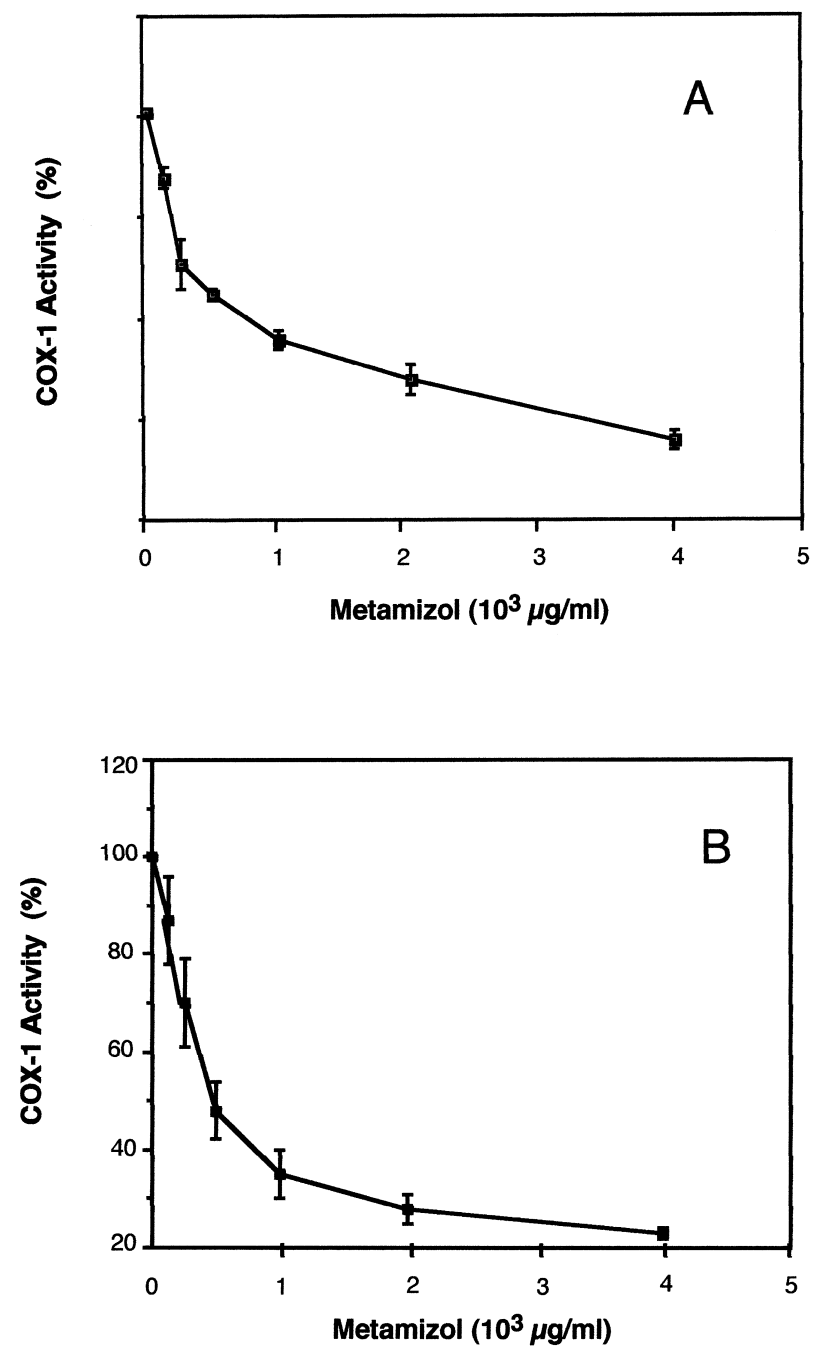

Fig. 3. Effects of metamizol on cyclooxygenase-1 activity measured in intact cells: (A) on BAEC cells measured as 6-keto-prostaglandin $F_{1 \alpha}$ formation after exposure to exogenous $30 \mu \mathrm{M}$ arachidonic acid for 10 min. $100 \%$ of activity $(1.6 \mathrm{ng} / \mathrm{ml} \pm 0.5)$ is given to the value without metamizol incubation. The data are expressed as mean \pm S.D. from three different experiments performed in duplicate; (B) on human platelets measured as thromboxane $B_{2}$ after stimulation with calcium ionophore for $5 \mathrm{~min}$. The data are expressed as mean \pm S.D. from three different experiments performed in duplicate.

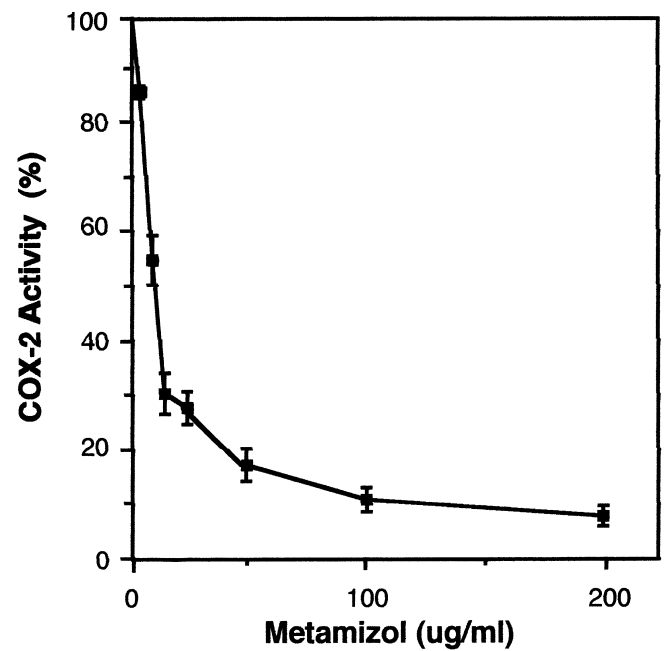

Fig. 4. Effect of metamizol on cyclooxygenase-2 activity measured in intact murine macrophages. Cells were treated with lipopolysaccharide for $12 \mathrm{~h}$ and cyclooxygenase- 2 activity was measured as prostaglandin $\mathrm{E}_{2}$ formation. $100 \%$ is given to the value of $860 \pm 35$ prostaglandin $/ \mathrm{ml}$ obtained in the absence of metamizol. The data are expressed as mean \pm S.D. from three different experiments performed in duplicate.

extend into a side pocket that is not accessible to inhibitors in cyclooxygenase-1. 4-Methylaminoantipyrine does not appear to exploit this adjacent binding pocket, the occupancy of which is thought to be important for achieving selectivity towards cyclooxygenase-2 (Kurumbail et al., 1996), and a similar binding mode can be envisaged for the other derivatives shown in Fig. 1A.

\subsection{Inhibition of purified cyclooxygenase-1 and cyclooxy- genase- 2 by metamizol}

Experiments to determine the activity of purified cyclooxygenase- 1 and cyclooxygenase- 2 in the presence of metamizol were carried out. Both enzymes were incubated with saturating concentrations of arachidonic acid in the presence of different concentrations of metamizol (60-2000 $\mu \mathrm{g} / \mathrm{ml}$ ). Consistent with the common binding mode reported above, we found that the inhibition curves of cyclooxygenase- 1 and cyclooxygenase- 2 activity by metamizol were very similar, the $\mathrm{IC}_{50}$ of metamizol being about 150 $\mu \mathrm{g} / \mathrm{ml}$ for either cyclooxygenase-1 or cyclooxygenase-2 (Fig. 2).

\subsection{Regulation of cyclooxygenase-1 activity in intact cells}

To measure the capacity of metamizol to inhibit cyclooxygenase- 1 and cyclooxygenase- 2 activities in a more physiological context, we next decided to use different intact cell systems as a source of cyclooxygenase-1 or cyclooxygenase-2 activities. BAEC cells do not contain cyclooxygenase- 2 but a constitutive cyclooxygenase- 1 activity, which results in a release of prostaglandins to the extracellular medium (Mitchell et al., 1994). High concentrations of metamizol in the incubation media resulted in a 

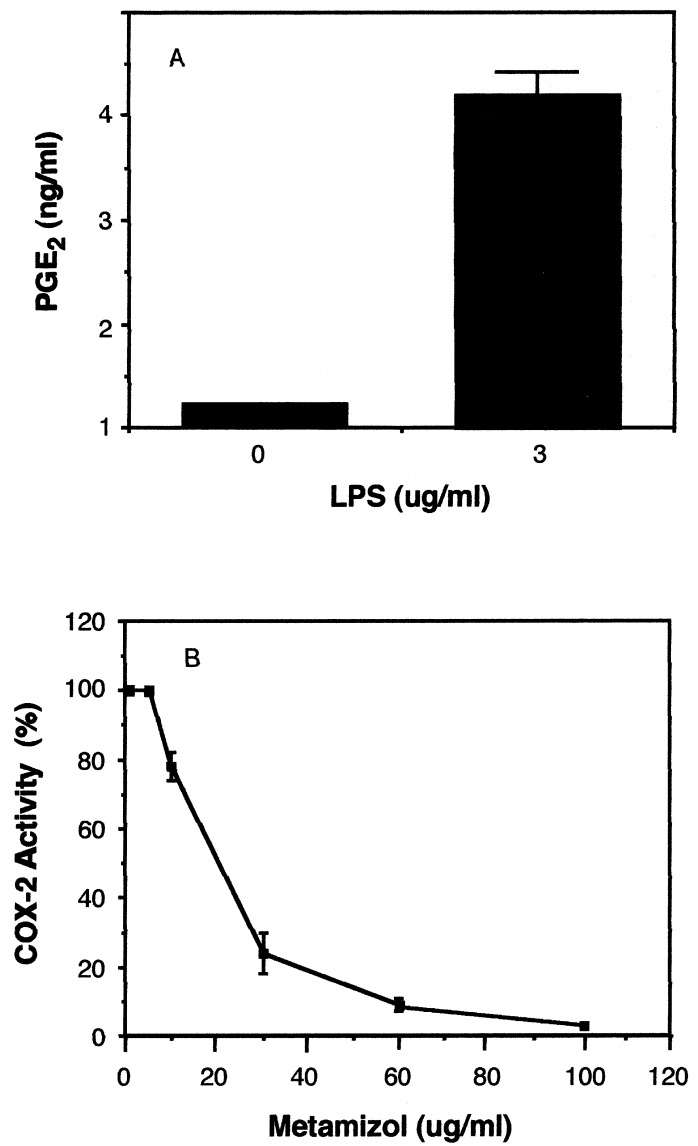

Fig. 5. Induction of cyclooxygenase-2 activity in human freshly isolated leukocytes and inhibition by metamizol. (A) Prostaglandin $\mathrm{E}_{2}$ levels in the incubation media after stimulation or not with $5 \mu \mathrm{g} / \mathrm{ml}$ lipopolysaccharide for $12 \mathrm{~h}$. The data are expressed as mean \pm S.D. from four different experiments performed in duplicate. (B) Inhibition of cyclooxygenase- 2 activity by metamizol measured as prostaglandin $\mathrm{E}_{2}$ formation. $100 \%$ is given to the value obtained in the absence of metamizol. The data are expressed as mean \pm S.D. from four different experiments performed in duplicate.

decrease of prostaglandins production. Metamizol, when added to the incubation media of BAEC cells, showed an $\mathrm{IC}_{50}$ for cyclooxygenase- 1 activity of $1730 \pm 150 \mu \mathrm{g} / \mathrm{ml}$, measured as the decrease in 6-keto-prostaglandin $\mathrm{F}_{1 \alpha}$ levels (Fig. 3A). The $\mathrm{IC}_{50}$ of indomethacin in these conditions was $8.5 \pm 0.5 \mu \mathrm{g} / \mathrm{ml}$ (data not shown).

We next decided to test the capacity of metamizol to inhibit cyclooxygenase-1 activity in human platelets as a model of freshly isolated intact human cells. Isolated platelets were incubated with calcium ionophore A23187 at a concentration of $0.25 \mu \mathrm{M}$ and cyclooxygenase-1 activity was measured as thromboxane production. As shown in Fig. 3B, the $\mathrm{IC}_{50}$ of metamizol for cyclooxygenase-1 was $486 \pm 56 \mu \mathrm{g} / \mathrm{ml}$.

\subsection{Regulation of cyclooxygenase-2 activity by metamizol in intact cells}

Murine monocyte-macrophage J774A.1 cells have been used as a model to determine cyclooxygenase- 2 activity
(Mitchell et al., 1994). No prostaglandin $\mathrm{E}_{2}$ levels were detected in the incubation media, unless cells were stimulated with lipopolysaccharide for $12 \mathrm{~h}$. In these conditions, and as a result of inducing cyclooxygenase- 2 expression, the concentration of prostaglandin $\mathrm{E}_{2}$ released to the incubation media in $30 \mathrm{~min}$ was $860 \pm 35 \mathrm{pg} / \mathrm{ml}$. Incubation with metamizol inhibited prostaglandin $\mathrm{E}_{2}$ release. The $\mathrm{IC}_{50}$ of metamizol for cyclooxygenase- 2 in this cell system was $12 \pm 1.8 \mu \mathrm{g} / \mathrm{ml}$ (Fig. 4). Incubation with indomethacin also inhibited the release of prostaglandin $\mathrm{E}_{2}$ with an $\mathrm{IC}_{50}$ of $0.23 \pm 0.016 \mu \mathrm{g} / \mathrm{ml}$ (data not shown).

Similar experiments to determine the $\mathrm{IC}_{50}$ of metamizol for cyclooxygenase- 2 in intact human primary cells were carried out using freshly isolated human leukocytes. Stimulation of these cells with $3 \mu \mathrm{g} / \mathrm{ml}$ lipopolysaccharide increased the prostaglandin $\mathrm{E}_{2}$ levels in the incubation media from $200 \pm 30$ up to $4200 \pm 400 \mathrm{pg} / \mathrm{ml}$ (Fig. 5A), as a result of cyclooxygenase- 2 induction. Incubation of leukocytes with metamizol dramatically decreased the levels of prostaglandin $\mathrm{E}_{2}$ in the incubation media, with an $\mathrm{IC}_{50}$ of $21 \pm 2.9 \mu \mathrm{g} / \mathrm{ml}$ (Fig. 5B).

\subsection{Determination of the $I C_{50}$ value of metamizol for cyclooxygenase-2 in cell extracts}

The 10-fold difference between the metamizol $\mathrm{IC}_{50}$ values for purified cyclooxygenase- 2 and in intact cells prompted us to determine the inhibitory capacity of metamizol on cyclooxygenase- 2 activity, using as a source of enzyme lipopolysaccharide-activated broken murine monocyte-macrophage cells. In these conditions, metamizol inhibited prostaglandin $\mathrm{E}_{2}$ synthesis with a $\mathrm{IC}_{50}$ of $145 \pm$ $18 \mu \mathrm{g} / \mathrm{ml}$ (Fig. 6). When indomethacin was tested in these conditions the $\mathrm{IC}_{50}$ obtained was $0.60 \pm 0.009$ $\mu \mathrm{g} / \mathrm{ml}$ (data not shown).

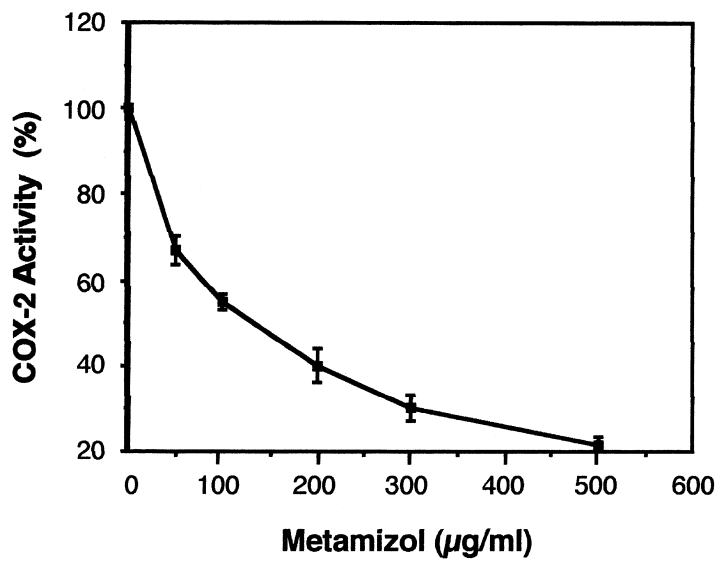

Fig. 6. $\mathrm{IC}_{50}$ of metamizol on cyclooxygenase-2 activity in broken lipopolysaccharide-activated murine macrophage preparation. Cell extracts were prepared as described under Section 2. Prostaglandin $E_{2}$ formation was measured after incubation with saturating doses of arachidonic acid in the presence of different doses of metamizol. The data are expressed as mean \pm from at least three different experiments performed in duplicate. 


\section{Discussion}

The discovery of an inducible isoform of cyclooxygenase allows a reinterpretation and refinement of cyclooxygenase activity inhibition, as well as an explanation of the therapeutic and side effects of NSAIDs. It is now accepted that the antiinflammatory and analgesic actions of NSAIDs are due to inhibition of cyclooxygenase-2 and the unwanted side effects such as gastric and renal toxicity are due to the inhibition of the constitutive enzyme cyclooxygenase-1. We have evaluated the ability of metamizol to inhibit cyclooxygenase- 1 and cyclooxygenase- 2 activities using different cyclooxygenase sources. We also propose a molecular model of the interaction between these enzymes and the main active derivative of metamizol based on automated docking calculations.

The common binding mode of 4-methylaminoantipyrine to cyclooxygenase- 1 and cyclooxygenase- 2 is in agreement with the data obtained with the purified enzymes showing metamizol to be equally potent in its inhibition of cyclooxygenase- 1 and cyclooxygenase- 2 activities, with an $\mathrm{IC}_{50}$ of about $150 \mu \mathrm{g} / \mathrm{ml}$. Metamizol also has an $\mathrm{IC}_{50}$ of about $150 \mu \mathrm{g} / \mathrm{ml}$ when tested for cyclooxygenase-2 inhibition in macrophage cell extracts.

Metamizol is substantially more potent (about 10-fold) in inhibiting cyclooxygenase- 2 activity when intact cells are used as a source of cyclooxygenase- 2 . The $\mathrm{IC}_{50}$ of about $12 \pm 1.8 \mu \mathrm{g} / \mathrm{ml}$ of metamizol for cyclooxygenase- 2 in intact lipopolysaccharide-activated murine monocytemacrophage cells is in accordance with previous data demonstrating that the inhibition of the release of a nociceptive factor from lipopolysaccharide-activated macrophages occurs at $3.5 \pm 0.35 \mu \mathrm{g} / \mathrm{ml}$ metamizol (Campos et al., 1988).

The low $\mathrm{IC}_{50}$ value $(15-20 \mu \mathrm{g} / \mathrm{ml})$ of metamizol for cyclooxygenase- 2 using intact cells as a source of cyclooxygenase-2 leads us to conclude that the analgesic effects described for metamizol (Brune, 1983; Matzner et al., 1984) can be due to cyclooxygenase- 2 inhibition since after drug administration the blood levels of the active derivatives of metamizol are about $30 \mu \mathrm{g} / \mathrm{ml}$ (Levy et al., 1995).

Our data also indicate that, although breaking the integrity of the cell plasma membrane should facilitate the access of metamizol to the endoplasmic reticulum and nuclear envelope, where cyclooxygenase-2 is located (Morita et al., 1995), cell disruption is in fact detrimental for cyclooxygenase inhibition by metamizol. Differences in $\mathrm{IC}_{50}$ values obtained in intact cells, broken cells, or purified enzymes have also been described for other NSAIDs (Barnett et al., 1994; Mitchell et al., 1994; Carabaza et al., 1996). The NSAID BF 389, for example, exhibits a 250 -fold lower $\mathrm{IC}_{50}$ value for cyclooxygenase-2 in intact cells when compared with the $\mathrm{IC}_{50}$ obtained with the purified enzyme (Mitchell et al., 1994). The reasons for these differences in the $\mathrm{IC}_{50}$ values depending on assay conditions remain to be established. It is conceivable that the conformation of the enzyme is altered upon membrane homogenization in such a way that it loses affinity for some inhibitors or, alternatively, that binding of some inhibitors is facilitated by another cellular component present only in intact cells.

In intact cells the $\mathrm{IC}_{50}$ value of metamizol for cyclooxygenase- 1 was more than 20 -fold higher than that obtained for cyclooxygenase-2, indicating that cyclooxygenase- 2 may be selectively inhibited by therapeutic concentrations of metamizol. In fact, its cyclooxygenase- 2 selectivity profile is superior to that of indomethacin (see Section 3) or other classical NSAIDs (Smith and DeWitt, 1994; Mitchell et al., 1994; Cashman, 1996). The $\mathrm{IC}_{50}$ value obtained for cyclooxygenase- 1 in human platelets is about 15-fold higher than the blood levels of metamizol after the administration of the drug (Levy et al., 1995). These data agree with the fact that the risk of gastrointestinal bleeding associated with metamizol use is comparable to that of paracetamol and clearly lower than that of acetylsalicylic acid and other NSAIDs (Laporte and Carne, 1987; Laporte et al., 1991).

Different authors, prior to the discovery of the cyclooxygenase-2 isozyme, had proposed that the ability of metamizol to inhibit prostaglandin synthesis depends on the biological system used, providing evidence that this inhibition was particularly potent in the brain (Dembinska-Kiec et al., 1976; Weithmann and Alpermann, 1985; Brodgen, 1986). The specificity of metamizol to inhibit prostaglandin synthesis in brain tissue can now be reinterpreted in the light of the selectivity shown by metamizol for cyclooxygenase-2 inhibition in intact cells. This selectivity could also underlie the pharmacological profile of this drug which is endowed with strong analgesic and antipyretic effects together with weak antiinflamatory activity.

In conclusion, in this paper we present evidence that the $\mathrm{IC}_{50}$ values obtained with purified enzymes or disrupted cells cannot always be extrapolated to the cyclooxygenase inhibitory capacity of the NSAIDs in intact cells and probably "in vivo". The data presented here also indicate that metamizol does not regulate cyclooxygenase-1 activity in intact cells at therapeutic concentrations and that the inhibition of cyclooxygenase- 2 achieved at these concentrations could play an important role in the analgesic effects of metamizol.

\section{Acknowledgements}

We thank the technical assistance of Joaquín Pérez. Rosa de Gregorio is supported by a "CSIC-sector empresarial" fellowship. Provision of programs GRID and AutoDock by Dr. Peter Goodford (Molecular Discovery, UK) and Dr. Garrett Morris (The Scripps Research Institute), respectively, is gratefully acknowledged. This work 
was supported by Plan Nacional, Comunidad de Madrid and Boehringer Ingelheim-Europharma.

\section{References}

Barnett, J., Chow, J., Ives, D., Chiou, M., Mackenzie, R., Osen, E., Nguyen, B., 1994. Purification, characterization and selective inhibition of human prostaglandin $\mathrm{G} / \mathrm{H}$ synthase 1 and 2 expressed in the baculovirus system. Biochim. Biophys. Acta 1209, 130-139.

Beirith, A., Santos, A.R.S., Rodrigues, A.L.S., Creczynski-Pasa, T.B., Calixto, J.B., 1998. Spinal and supraspinal antinociceptive action of dipyrone in formalin, capsaicin and glutamate tests. Study of the mechanism of action. Eur. J. Pharmacol. 345, 233-245.

Besler, B.H., Merz, K.M. Jr., Kollman, P.A., 1990. Atomic charges derived from semiempirical methods. J. Comp. Chem. 11, 431-439.

Brodgen, R.N., 1986. Pyrazolone derivatives. Drugs 32, 60-70, Suppl. 4.

Brune, K., 1983. Prostglandins and the mode of action of antipyretic analgesic drugs. Am. J. Med. 14, 19-23.

Campos, D.I., Cunha, F.Q., Ferreira, S.H., 1988. A new mechanism of action of dipyrone: blockade of the release of a nociceptive factor from macrophages. Brasilian J. Med. Biol. Res. 21, 565-568.

Carabaza, A., Cabre, F., Rotllan, E., Gomez, M., Gutierrez, M., Garcia, M.L., Mauleon, D., 1996. Stereoselective inhibition of inducible cyclooxygenase by chiral nonsteroidal antiinflammatory drugs. J. Clin. Pharmacol. 36, 505-512.

Carlsson, K.H., Helmreich, J., Jurna, I., 1986. Activation of inhibition from the periaqueductal grey matter mediates central analgesic effect of metamizol (dipyrone). Pain 27, 373-390.

Cashman, J.N., 1996. The mechamisn of action of NSAIDs in analgesia. Drugs 52, 13-23, Suppl. 5.

Coffey, R.J., Hawkey, C.J., Damstrup, L., Graves-Deal, R., Daniel, V.C., Dempsey, P.J., Chinery, R., Kirkland, S.C., DuBois, R.N., Jetton, T.L., Morrow, J.D., 1997. Epidermal growth factor receptor activation induces nuclear targeting of cyclooxygenase-2, basolateral release of prostaglandins and mitogenesis in polarizing colon cancer cells. Proc. Natl. Acad. Sci. U.S.A. 94, 657-662.

Dembinska-Kiec, A., Zmuda, A., Kupinska, J., 1976. Inhibition of prostaglandin synthetase by aspirin-like drugs in different microsomal preparations. In: Samuesson, B., Pooletti, R. (Eds.), Adv. in Prostaglandin and Thromboxane Research, Vol. 1. Raven Press, New York.

Dewar, M.J.S., Zoebisch, E.G., Healy, E.F., Stewart, J.J.P., 1985. AM1: a new general purpose quantum mechanical molecular model. J. Am. Chem. Soc. 107, 3902-3909.

DeWitt, D.L., Meade, E.A., 1993. Serum and glucocorticoid regulation of gene transcription and expression of the prostaglandin $\mathrm{H}$ synthase-1 and prostaglandin synthase-2 isozymes. Arch. Biochem. Biophys. 306, 94-102.

Dirig, D.M., Konin, G.P., Isakson, P.C., Yaksh, L.T., 1997. Effect of spinal cyclooxygenase inhibitors in rat using the formalin test and in vitro prostaglandin $\mathrm{E}_{2}$ release. Eur. J. Pharmacol. 331, 155-160.

Eldor, A., Zylber-Katz, E., Levy, M., 1984. The effects of oral administration of dypirone on the capacity of blood platelets to synthesize thromboxane $\mathrm{A}_{2}$ in man. Eur. J. Clin. Pharmacol. 26, 171-176.

Font, J., Azula, F.J., Marino, A., Nieva, N., Trueba, M., Macarulla, J.M., 1992. Intracellular $\mathrm{Ca}_{2}{ }^{+}$mobilization and not calcium influx promotes phorbol ester-stimulated thromboxane $\mathrm{A}_{2}$ synthesis in human platelets. Prostaglandins 43, 383-395.

Funk, C.D., Funk, L.B., Kennedy, M.E., Pong, A.S., Fitzgerald, G.A., 1991. Human platelet/erythroleukemia cell prostaglandin G/H synthase cDNA cloning, expression, and gene chromosomal assignment. FASEB J. 5, 2304-2312.

García-Nieto, R., Pérez, C., Gago, F., 1999. Automated docking and molecular dynamics simulations of nimesulide in the cyclooxygenase active site of human prostaglandin-endoperoxide synthase-2 (COX-2). J. Comp.-Aided Mol. Design, in press.
Gelgor, L., Cartmell, S., Mitchell, D., 1992. Intracerebroventricular micro-injections of non-steroidal anti-inflammatory drug abolish reperfusion hyperalgesia in the rat's tail. Pain 50, 323-329.

Gierse, J.K., Mcdonald, J.J., Hauser, S.D., Rangwala, S.H., Koboldt, C.M., Seibert, K., 1996. A single amino acid difference between cyclooxygenase- 1 and -2 reverses the selectivity of cyclooxygenase-2 specific inhibitors. J. Biol. Chem. 271, 15810-15814.

Goodford, P.J.A., 1985. Computational procedure for determining energetically favorable binding sites on biologically important macromolecules. J. Med. Chem. 28, 849-857.

Guo, Q., Wang, L.H., Ruan, K.H., Kulmacz, R.J., 1996. Role of Val ${ }^{509}$ in time-dependent inhibition of human prostaglandin $\mathrm{H}$ synthase-2 cyclooxygenase activity by isoform-selective agents. J. Biol. Chem. 271, 19134-19139.

Kraemer, S.A., Meade, E.A., Dewitt, D.L., 1992. Prostaglandin endoperoxide synthase gene structure identification of the transcriptional start site and $5^{\prime}$ flanking regulatory sequences. Arch. Biochem. Biophys. 293, 391-400.

Kraulis, P.J., 1991. Molscript: a program to produce both detailed and schematic plots of protein structures. J. Appl. Crystall. 24, 946-950.

Kujubu, D.A., Fletcher, B.S., Varnum, B.C., Lim, R.W., Herschman, H.R., 1991. TIS10, a phorbolester tumor promoter-inducible mRNA from Swiss 3T3 cells, encodes a novel prostaglandin synthase/cyclooxygenase homologue. J. Biol. Chem. 266, 12866-12872.

Kurumbail, R.G., Stevens, A.M., Gierse, J.K., McDonald, J.J., Stegeman, R.A., Pak, J.Y., Gildehaus, D., Miyashiro, J.M., Penning, T.D., Seibert, K., Isakson, P.C., Stallings, W.C., 1996. Structural basis for selective inhibition of cyclooxygenase- 2 by anti-inflammatory agents. Nature 384, 644-648.

Laporte, J.R., Carne, X., 1987. Blood dyscrasias and the relative safety of non-narcotic analgesics. Lancet 4, 809-811.

Laporte, J.R., Carne, X., Vidal, X., Moreno, V., Juan, J., 1991. Upper gastrointestinal bleeding in relation to previous use of analgesics and non-steroidal anti-inflammatory drugs. Catalan countries study on upper gastrointestinal bleeding. Lancet 337, 85-89.

Lee, S.H., Soyoola, E., Chanmugam, P., Hart, S., Sun, W., Zhong, H., Liou, S., Simmons, D., Hwang, D., 1992. Selective expression of mitogen-inducible cyclooxygenase in macrophages stimulated with lipopolysaccharide. J. Biol. Chem. 267, 25934-25938.

Levy, M., 1986. Pharmakokinetics of metamizol metabolites. Agents Actions Suppl. 19, 199-204.

Levy, M., Zylber-Katz, E., Rosenkranz, B., 1995. Clinical pharmacokinetics of dipyrone and its metabolites. Clin. Pharmacokinet. 28, 216-234.

Lorenzetti, B.B., Ferreira, S.H., 1985. Mode of analgesic action of dipyrone: direct antagonism of inflammatory hyperalgesia. Eur. J. Pharmacol. 114, 375-381.

Matzner, Y., Drexler, R., Levy, M., 1984. Effect of dipyrone, acetylsalicylic acid and acetaminophen on human neutrophil chemotaxis. Eur. J. Clin. Invest. 14, 440-443.

McCormak, K., 1994. Non-steroidal anti-inflammatory drugs and spinal nociceptive processing. Pain 59, 9-43.

Mitchell, J.A., Akarasereenont, P., Thiemermann, C., Flower, R.J., Vane, J.R., 1994. Selectivity of nonsteroidal antiinflammatory drugs as inhibitors of constitutive and inducible cyclooxygenase. Proc. Natl. Acad. Sci. U.S.A. 90, 11693-11697.

Morita, Y., Schindler, M., Regier, M.K., Otto, J.C., Hori, T., DeWitt, D.L., Smith, W.L., 1995. Different intracellular locations for prostaglandin endoperoxidase H synthase-1 and -2. J. Biol. Chem. 270, 10902-10908.

Morris, G.M., Goodsell, D.S., Huey, R., Olson, A.J., 1996. AutoDock: automated docking of flexible ligands to receptors, version 2.4. The Scripps Research Institute, La Jolla, CA 92037-5025.

Pairet, M., Engelhardt, G., 1996. Distinct isoforms (COX-1 and COX-2) of cyclooxygenase: possible physiological and therapeutic implications. Fundam. Clin. Pharmacol. 10, 1-15.

Picot, D., Loll, P.J., Garavito, R.M., 1994. The X-ray crystal structure of 
the membrane protein prostaglandin $\mathrm{H}_{2}$ synthase-1. Nature 367, 243-249.

Ristimaki, A., Garfinkel, S., Wessendrof, J., Maciag, T., Hla, T., 1994. Induction of cyclooxygenase-2 by interleukin-1. J. Biol. Chem. 269, 11769-11775.

Simmons, D.L., Xie, W., Chipman, J.G., Evett, G.E., 1991. Multiple cyclooxygenases: cloning of a mitogen-inducible form. In: Bailey, J.M. (Ed.), Prostaglandins, Leukotrienes, Lipoxins, and PAF. Plenum, New York, 67-78.

Smith, W.L., DeWitt, D.L., 1994. Differential interactions of prostaglandin endoperoxide synthase with nonsteroidal anti-inflammatory drugs. Curr. Opin. Invest. Drugs 3, 1-11.

Smith, W.L., Sonnenburg, W.K., Allen, M.L., Watanabe, T., Zhu, J., El-Harith, E.A., 1989. The biosynthesis and actions of prostaglandin in the renal collecting tubule and thick ascending limb. In: Dunn, M.J., Patrono, C., Cinotti, G.A. (Eds.), Renal Eicosanoids. Plenum, New York, 131-148.

Smith, C.J., Zhang, Y., Koboldt, C.M., Muhammad, J., Zweifel, B.S., Shaffer, A., Talley, J.J., Masferrer, J.L., Seibert, K., Isakson, P.C., 1998. Prostaglandin biosynthesis and its compartmentation in vascular smooth muscle and endothelial cells. Annu. Rev. Physiol. 48, 251262.

Tavares, I.A., Bennett, A., 1993. Acemetacin and indomethacin: differential inhibition of constitutive and inducible cyclo-oxygenases in human gastric mucosa and leucocytes. Int. J. Tiss. React. XV, 49-53.
Taylor, J., Mellström, B., Fernaud, I., Naranjo, J.R., 1998. Metamizol potentiates morphine effects on visceral pain and evoked c-Fos immunoreactivity in spinal cord. Eur. J. Pharmacol. 351, 39-47.

Tortorici, V., Vanegas, H., 1995. Anti-nociception induced by systemic or PAG-microinjected lysine-acetylsalicylate in rats. Effects on tailflick related activity of medullary off- and on-cells. Eur. J. Neurosci. 7, 1857-1865.

Vane, J.R., Botting, R.M., 1998. Mechanism of action of nonsteroidal anti-inflammatory drugs. Am. J. Med. 104, 2-8.

Vane, J.R., Bakhle, Y.S., Botting, R.M., 1998. Cyclooxygenases 1 and 2. Annu. Rev. Pharmacol. Toxicol. 38, 97-120.

Vlahov, V., Badian, M., Verho, M., Bacracheva, N., 1990. Pharmacokinetics of metamizol metabolites in healthy subjects after a single oral dose of metamizol sodium. Eur. J. Clin. Pharmacol. 38, 61-65.

Weithmann, K.U., Alpermann, H.-G., 1985. Biochemical and pharmacological effects of dipyrone and its metabolites in a model system related to arachidonic acid cascade. Arzneimittel-forschung 35, 947952

Yaksh, T.L., Dirig, D.M., Malmberg, A.B., 1998. Mechanism of action of nonsteroidal anti-inflammatory drugs. Cancer Invest. 16, 509-527.

Yokoyama, C., Tanabe, T., 1989. Cloning of human gene encoding prostaglandin endoperoxide synthase and primary structure of the enzyme. Biochem. Biophys. Res. Commun. 165, 888-894. 